II presente documento viene fornito attraverso il servizio NILDE dalla Biblioteca fornitrice, nel rispetto della vigente normativa sul Diritto d'Autore (Legge n.633 del 22/4/1941 e successive modifiche e integrazioni) e delle clausole contrattuali in essere con il titolare dei diritti di proprietà intellettuale.

La Biblioteca fornitrice garantisce di aver effettuato copia del presente documento assolvendo direttamente ogni e qualsiasi onere correlato alla realizzazione di detta copia.

La Biblioteca richiedente garantisce che il documento richiesto è destinato ad un suo utente, che ne farà uso esclusivamente personale per scopi di studio o di ricerca, ed è tenuta ad informare adeguatamente i propri utenti circa i limiti di utilizzazione dei documenti forniti mediante il servizio NILDE.

La Biblioteca richiedente è tenuta al rispetto della vigente normativa sul Diritto d'Autore e in particolare, ma non solo, a consegnare al richiedente un'unica copia cartacea del presente documento, distruggendo ogni eventuale copia digitale ricevuta.

Biblioteca richiedente: Biblioteca del Dipartimento di Scienze per la Promozione della Salute e Materno Infantile. Sett. Materno Infantile

Data richiesta:

$11 / 11 / 201310: 46: 44$

Biblioteca fornitrice: Biblioteca IRCCS Ospedale Generale Regionale Casa Sollievo della Sofferenza S Giovanni Rotondo (FG)

Data evasione:

$11 / 11 / 201312: 41: 51$

Titolo rivista/libro:

Fertility and sterility

Titolo articolo/sezione: Detection of oncogenic human papillomavirus genotypes on spermatozoa from male partners of infertile couples

Autore/i:

schillaci R

ISSN:

0015-0282

DOI:

Anno:

Volume:

100

Fascicolo:

5

Editore:

Pag. iniziale:

Pag. finale: 


\section{Detection of oncogenic human papillomavirus genotypes on spermatozoa from male partners of infertile couples}

Rosaria Schillaci, Ph.D., ${ }^{a}$ Giuseppina Capra, Ph.D., ${ }^{a}$ Carmela Bellavia, Ph.D., ${ }^{a}$ Giovanni Ruvolo, Ph.D., Concetta Scazzone, Ph.D., ${ }^{b}$ Renato Venezia, M.D., ${ }^{a}$ and Antonio Perino, M.D. ${ }^{a}$

a Dipartimento di Scienze per la Promozione della Salute e Materno Infantile "G. d'Alessandro" and b Dipartimento di Biopatologia e Biotecnologie Mediche e Forensi, University of Palermo; and ' Centro di Biologia della Riproduzione, Palermo, Italy

Objective: To evaluate the prevalence of human papillomavirus (HPV) sperm infection and its correlation with sperm parameters in patients who attended a fertility clinic.

Design: Cross-sectional clinical study.

Setting: University-affiliated reproductive medicine clinic.

Patient(s): A total of 308 male partners of couples undergoing in vitro fertilization techniques.

Intervention(s): Specimens of semen were collected from all patients.

Main Outcome Measure(s): Sperm parameters were evaluated according to the World Health Organization manual. The presence of HPV DNA was researched by the combined use of two HPV assays and a highly sensitive nested polymerase chain reaction assay followed by HPV genotyping. To examine whether HPV was associated with the sperm, in situ hybridization (ISH) analysis was performed. Result(s): Results of HPV investigation were compared with sperm parameters and ISH analysis. Twenty-four out of 308 semen samples $(7.8 \%)$ were HPV DNA positive, but HPV infection did not seem to affect semen quality. Moreover, ISH revealed a clear HPV localization at the equatorial region of sperm head in infected samples.

Conclusion(s): Oncogenic HPV genotypes were detected on spermatozoa from asymptomatic subjects, but a role of the infection in male infertility was not demonstrated. (Fertil Steril ${ }^{\circledR}$ 2013;100:1236-40. (C) 2013 by American Society for Reproductive Medicine.)

Key Words: HPV infection, semen parameters, IVF, ICSI

Discuss:You can discuss this article with its authors and with other ASRM members at http:// fertstertforum.com/schillacir-hpv-ivf-icsi-spermatozoa/

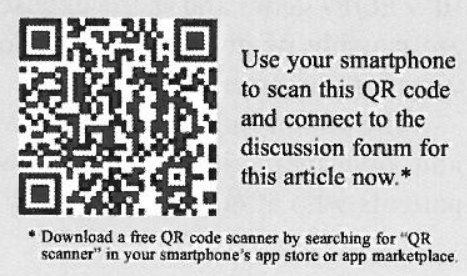

$\mathrm{H}$ uman papillomaviruses (HPVs) are agents of the most common sexually transmitted disease. These small DNA viruses induce epithelial cell proliferation, and high risk HPV types cause almost all cases of cervical cancers and a variable proportion of noncervical malignancies, including vulvar, vaginal, anal, and oropharin- geal, and cancer of the penis (1). Many studies have focused on HPVrelated diseases in women, whereas fewer data are available on male infection. It is estimated that the prevalence of any HPV type in men ranged from $1.3 \%$ to $72.9 \%$, with a prevalence of $65.4 \%$ in some age groups, especially among individuals 18-40 years of age

Received February 14, 2013; revised June 11, 2013; accepted June 24, 2013; published online July 24 2013.

R.S. has nothing to disclose. G.C. has nothing to disclose. C.B. has nothing to disclose. G.R. has nothing to disclose. C.S. has nothing to disclose. R.V. has nothing to disclose. A.P. has nothing to disclose. Reprint requests: Rosaria Schillaci, Ph.D., Clinica Ostetrica e Ginecologica, Dipartimento di Scienze per la Promozione della Salute e Materno Infantile, Via Alfonso Giordano 3, 90127 Palermo, Italy (E-mail: rosaria.schillaci@unipa.it).

Fertility and Sterility@ Vol. 100, No. 5, November 2013 0015-0282/ $\$ 36.00$

Copyright $\odot 2013$ American Society for Reproductive Medicine, Published by Elsevier Inc. http://dx.doi.org/10.1016/j.fertnstert.2013.06.042

$(2,3)$. Although HPV infection in men may be associated with low mortality and morbidity, investigation is still important owing to both its association with genital warts, penile cancer, anorectal cancer, and oropharyngeal cancer, and the role men play in HPV transmission to their female sexual partners $(4,5)$. In men, HPV DNA and RNA have been found not only in the penile shaft, glans, and urethra (3), but also in the ductus deferens, epididymis, and testis $(6,7)$.

Because the presence of the virus has also been demonstrated in semen (8), there is a growing interest in the impact of HPV infection on male fertility and reproductive function. 
Although data from recent studies suggest that placental HPV infection in early pregnancy can occur via infected sperm at fecundation (9) and reveal a possible role of HPV male infection as a cause of miscarriage in couples undergoing assisted reproduction technology cycles (10), the effect of infection on semen parameters is still a controversial topic. Some authors report that HPV infection is associated with reduced sperm motility (11-15), raising concerns about its possible role in idiopathic asthenozoospermia and thus in male infertility. Additionally, a very recent study by Garolla et al. (16) hypothesizes that HPV may impair sperm motility owing to higher antisperm antibody (ASA) production. On the other hand, other authors failed to observe any relation among sperm viral infection, ASA production, and sperm quality $(17,18)$.

However, precise data about the presence and significance of HPV in sperm are not available. In particular, the exact localization and mechanism of infection by HPV in sperm, as well as the role of infected sperm cells as a transmission vector for the virus are still unclear. A study by Perez-Andino et al. (19) revealed that HPV-16 capsids bind efficiently to two distinct sites at the equatorial region of the sperm head surface, suggesting that these sites may mediate HPV binding. Other observations of HPV-6, $-16,-18$, and -31 association to or near the sperm head equatorial segment were documented in sperm donors (20). Recently, Foresta et al. (21) revealed a possible mechanism of infection by HPV in human sperm based on the interaction between the capsid-protein L1 and the primary attachment receptor syndecan-1 localized at the equatorial region of the sperm head. Sperm transfected with HPV E6/E7 genes and sperm exposed to HPV L1 capsid protein are capable of penetrating the oocyte and transferring the virus into hamster eggs (21).

The aim of the present study was to detect HPV in semen and investigate its correlation with sperm parameters in patients who attended our fertility clinic.

\section{MATERIALS AND METHODS Patients}

A cohort of 308 male partners of couples undergoing conventional in vitro fertilization (IVF) or intracytoplasmic sperm injection (ICSI), after signing an informed consent, were enrolled in the study at the Reproductive Medicine Unit, University of Palermo, Italy, and the Centro di Biologia della Riproduzione, Palermo, Italy, from October 2010 to October 2012. Institutional Review Board approval was obtained before starting the study. No patient tested positive for HIV, Chlamydia trachomatis, Neisseria gonorrhoeae, Herpes simplex, or Treponema pallidum. All subjects, aged 28 to 57 years (mean $38.7 \pm 5.9$ years), collected semen for standard sperm analyses and examination for HPV DNA.

\section{Semen Processing}

Semen samples were obtained by masturbation after 3-5 days of sexual abstinence. After liquefaction at room temperature, semen volume, $\mathrm{pH}$, sperm concentration, motility, and normal morphology were evaluated according to World
Health Organization guidelines for semen analyses (22). Sperm cells were then separated by swim-up technique. After centrifugation at $300 \mathrm{~g}$ for 7 minutes, supernatants were discarded and $0.3 \mathrm{~mL}$ of fertilization medium (Origio; Medicult) was added to the pellet for ICSI procedure or $1 \mathrm{~mL}$ of the same medium for IVF insemination. Samples were then incubated at $37^{\circ} \mathrm{C}$ in $5 \% \mathrm{CO}_{2}$ for 45 minutes.

\section{Detection of HPV DNA}

After ICSI/IVF insemination, the supernatant was centrifuged at $300 \mathrm{~g}$ for 7 minutes and the pellet fixed in Preservcyt Solution (Cytyc Corp.). HPV testing was then performed directly on sperm cells. All semen samples were processed for DNA extraction (23). Amplifications were carried out in a Mastercycler (Eppendorf) and polymerase chain reaction (PCR) products were analyzed in 8\% polyacrylamide gel. HPV detection and typing were performed with the combined use of the HPV Inno-Lipa Genotyping System (Innogenetics) (24) and a nested PCR assay with PGMY09/11 and GP05+/06+ primer pairs, followed by direct cycle sequencing of PCR products for HPV genotyping. HPV genotypes were considered to be low risk or high risk according to two recently published epidemiologic classifications of HPV types (25).

\section{Semen In Situ Hybridization}

Sperm in situ hybridization (ISH) for HPV was a modification of the procedure described by Sarrate et al. (26). Briefly, after separation by swim-up procedure, samples containing $\geq 1 \times$ $10^{6}$ sperm were permeabilized with $0.075 \mathrm{~mol} / \mathrm{L} \mathrm{KCl}$ and incubated for 30 minutes at $37^{\circ} \mathrm{C}$ in a water bath. After centrifugation for 5 minutes at $1,000 \mathrm{~g}$, the supernatant was removed, the pellet fixed in a methanol-acetic acid solution for $\geq 24$ hours at $-20^{\circ} \mathrm{C}$, and $10 \mu \mathrm{L}$ sperm sample smeared on clean greasefree slides. After dehydration, samples were incubated in a solution of $5 \mathrm{mmol} / \mathrm{L}$ [1,4-dithiothreitol, $1 \%$ Triton X-100, and $50 \mathrm{mmol} / \mathrm{L} \quad$ 2-amino-2-(hydroxymethyl)-1,3-propanediol] for 8 minutes at $37^{\circ} \mathrm{C}$ to induce chromatin decondensation. Denaturation and hybridization were performed with a commercial kit (Zytofast HPV- Screening Plus CISH; Zytovision).

Samples were overlaid with $10 \mu \mathrm{L}$ hybridization solution containing digoxigenin (DIG)-labeled HPV DNA probe (Zytofast HPV 6/11/16/18/31/33/35 probe). Each slide was then covered with a glass coverslip, denaturated at $75^{\circ} \mathrm{C}$ for $5 \mathrm{mi}-$ nutes, and hybridized at $37^{\circ} \mathrm{C}$ for 60 minutes in a Thermobrite System (Iris Sample Processing).

Thereafter, slides were washed twice in $1 \times$ Tris-buffered solution (TBS) and incubated with three to four drops of mouse anti-DIG per slide for 30 minutes at $37^{\circ} \mathrm{C}$. After three washes in $1 \times$ TBS, three to four drops of anti-mouse horseradish polymerase per slide were added to the samples, which were then incubated for 30 minutes at $37^{\circ} \mathrm{C}$. Incubation was followed by three washes in $1 \times$ TBS.

After the addition of 3,3-diaminobenzidine tetrahydrochloride and nuclear blue solutions, samples were washed in water, dehydrated in ethanol (70\%-85\%-95\%-100\%), and then incubated in xylene for 2 minutes. The negative control sample was processed in the same manner. 
After drying, evaluation of sample material was carried out by light microscopy with $\times 100$ magnification.

\section{Statistical Analysis}

Data were analyzed with SPSS version 13.0. Significant differences between groups with or without HPV were determined by the Mann-Whitney test at $P<.05$.

\section{RESULTS}

A total of 308 semen samples were analyzed from patients who attended our fertility clinic, with an average age of $38.7 \pm 5.9$ years: $7.8 \%(24 / 308)$ tested positive for HPV and $41.6 \%$ of these (10/24) had an infected female partner. As reported in Table 1, most genotypes were of high risk, and a prevalence of HPV-52 $(5 / 24 ; 21 \%)$ was found. Among the 24 patients, 83.3\% (20/24) presented high-risk HPV and 16.7\% (4/24) low-risk HPV. In $16.7 \%(4 / 24)$ of the samples, more than one HPV type was detected, and all multiple infections included high-risk viral types. Among the ten infected couples, 40\% $(4 / 10)$ showed concordance of all viral types and 50\% (5/10) concordance of at least one. In particular, $90 \%(9 / 10)$ of semen samples presented high-risk HPV and 10\% (1/10) low-risk HPV. Moreover, in $40 \%(4 / 10)$ of the infected couples, a multiple infection by high-risk HPV was detected.

No statistically significant difference was found in sperm parameters between HPV-infected and noninfected semen samples (Table 2). Median value of sperm concentration was $10 \times 10^{6} / \mathrm{mL}$ and $15 \times 10^{6} / \mathrm{mL}$ in HPV-positive and HPV-negative men, respectively $(P=.19)$. HPV-infected and

\section{TABLE 1}

Type of human papillomavirus (HPV) infection in 24 infected patients undergoing IVF treatment and concordance of viral types between sexual partners.

$\begin{array}{lcc}\text { ID } & \text { HPV, female } & \text { HPV, male } \\ 28 & 59,66 & 59,61,66,84 \\ 31 & & 59,73 \\ 37 & & 59 \\ 78 & & 16 \\ 84 & 87 & 83 \\ 156 & 16,31 & 87 \\ 159 & 66 & 16,31 \\ 176 & & 16 \\ 203 & & 18,44,59,52 \\ 210 & & 52 \\ 213 & 59,66 & 53 \\ 216 & & 51 \\ 221 & & 31 \\ 224 & & 66 \\ 228 & & 51 \\ 235 & & 51 \\ 237 & 70 & 70 \\ 241 & 39 & 39 \\ 247 & 18 & 33 \\ 271 & & 54 \\ 280 & & 52 \\ 282 & & 52 \\ 289 & & 52 \\ 306 & 18,31 & 44 \\ \text { Schillaci Oncogenic HPV genotypes in sperm. Fertil Steril 2013. } & \\ & & \end{array}$

\section{TABLE 2}

Human papillomavirus (HPV) infection and sperm parameters in patients undergoing IVF treatment.

$\begin{array}{lccc} & \text { Infected }(\mathbf{n = 2 4 )} & \begin{array}{c}\text { Noninfected } \\ (\mathbf{n}=284)\end{array} & \boldsymbol{P} \text { value } \\ \text { Age, y } & 38.9 \pm 6.7 & 38.7 \pm 5.9 & .88^{\mathrm{a}} \\ \text { Sperm volume, } \mathrm{mL} & 3.5(2) & 3(2) & .56^{\mathrm{b}} \\ \mathrm{pH} & 7.5(0.2) & 7.45(0.23) & .40^{\mathrm{b}} \\ \text { Sperm number, } 10^{6} / \mathrm{mL} & 10(39.2) & 15(35) & .19^{\mathrm{b}} \\ \text { Motility a+b, \% } & 30(45) & 20(40) & .63^{\mathrm{b}} \\ \text { Motility c, \% } & 20(15) & 20(20) & .06^{\mathrm{b}} \\ \text { Normal morphology, \% } & 60(35) & 55(25) & .70^{\mathrm{b}}\end{array}$

Note: Values are presented as mean \pm SD or median (interquartile range)

a Student $t$ test.

${ }^{6}$ Mann-Whitney test

Schillaci. Oncogenic HPV genotypes in sperm. Fertil Steril 2013.

noninfected semen samples had similar rapid/slow progressive motility (medians $30 \%$ vs. $20 \% ; P=.63$ ) and nonprogressive motility (medians $20 \%$ vs. $20 \% ; P=.06$ ). We found no relationship between HPV infection and sperm volume (medians 3.5 vs. $3 ; P=.56$ ), $\mathrm{pH}$ (medians 7.6 vs. $7.4 ; P=.40$ ) or normal morphology (medians $60 \%$ vs. $55 \% ; P=.70$ ) evaluated in HPV-positive patients and HPV-negative patients, respectively.

Regarding the transmission of HPV infection, ISH performed on HPV-infected semen samples clearly showed attachment of HPV to the equatorial region of the sperm head, supporting the observation of other authors regarding mechanism of entry of the virus into the sperm (19-21) (Fig. 1).

\section{DISCUSSION}

According to study results, HPV infection was prevalent in $7.8 \%$ of the male partners of infertile couples with a detection

\section{FIGURE 1}

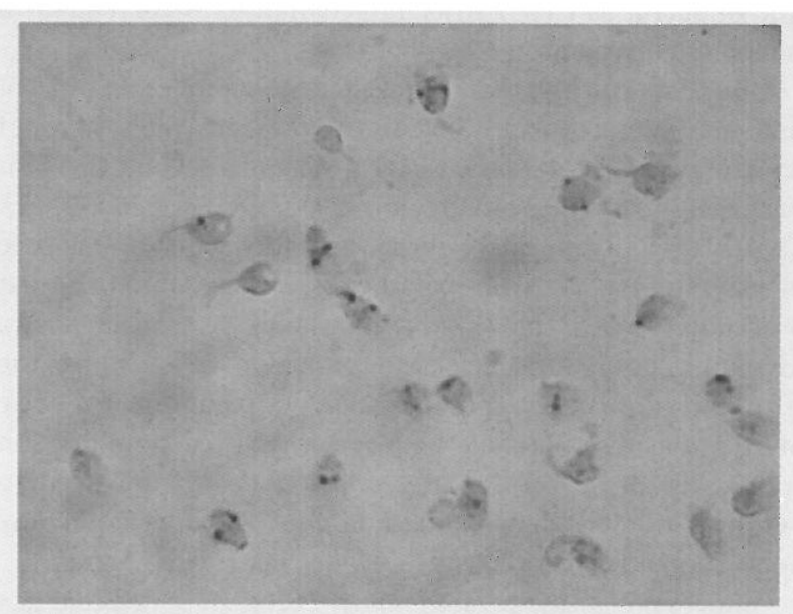

Detection and localization of human papillomavirus (HPV) in human sperm. In situ hybridization for HPV DNA on sperm from a patient with HPV-16 in semen.

Schillaci. Oncogenic HPV genotypes in sperm. Fertil Steril 2013. 
of high-risk HPV in $83.3 \%$ of positive seminal samples; HPV52 was the most prevalent viral type. Earlier data from a Mexican study (27) reported a higher prevalence of HPV infection (59.73\%) in semen samples from patients in an assisted reproduction program. That study also revealed that infection with HPV-16 was more frequent in both oligozoospermic and normozoospermic patients. In the latter, a minor presence of abnormal spermatic cells and leukocytes were found compared with oligozoospermic patients. A possible explanation for the evident discrepancy in the HPV prevalence and distribution identified in these two studies includes different geographic areas, sociodemographic characteristics, behavioral/lifestyle factors, sexual behavior between male samples studied, and detection techniques performed $(2,28-31)$.

Seminal HPV infection was frequently associated with reduced sperm motility (12-15), although other studies did not find any effects on sperm quality (8). The striking differences in literature data could be related to the relatively small sample size of cohorts evaluated in the different studies. For this reason, a multicenter study would be needed. Recently, Garolla et al. (16) reported that HPV sperm infection can be frequently associated with ASAs and lower sperm motility leading to a reduction of male fertility. This finding is in contrast with other observations that excluded the existence of a relationship between sperm viral infection, ASAs production, and sperm quality alteration $(17,18)$. However, in a previous study (10) we demonstrated that pregnancy and implantation rates were not affected by HPV infection in the men of couples undergoing IVF, but HPV positivity of semen from male partners increased the pregnancy loss rate compared with noninfected patients ( $66 \%$ vs. $15 \%$ ).

Thus, in accordance with data from Rintala et al. (8), our results suggest that HPV infection is not associated with an impairment of sperm parameters. Moreover, the recent detection of HPV in 16\% of semen samples from 188 healthy Danish donors (20) and the observation of an early placental HPV infection occurring in noninfected women (9) suggest a role of sperm as HPV carrier rather than its involvement in semen quality alteration.

Our data confirm that the mechanism of infection by HPV in human sperm probably consists, as previously described, of an interaction between the HPV capsid and a specific receptor localized in the equatorial region of the sperm head (19-21). The HPV ability to infect sperm, together with the absence of alterations of sperm parameters, entails the risk that procedures such as intracytoplasmic sperm injection, involving no natural selection of sperm cells, could use HPV-carrying sperm. These data suggest caution in the use of HPV-positive seminal samples for assisted reproduction techniques or sperm banking and emphasize the need to perform the HPV screening in the general infertility population.

Moreover, in the present study, 10/24 HPV-infected patients $(41.6 \%)$ had a female partner who was HPV positive, with 9/10 (90\%) presenting high-risk HPV. None of the male partners presented any visible lesions, although it has been reported that penile lesions are more frequent in partners of high- risk HPV carriers (32). Concordance of at least one viral type was found in $50 \%$ of the infected couples (5/10), suggesting that HPV-infected men could have an important role in transmission to women and maintenance of infection; as a consequence, there is a higher risk of developing cervical cancer. Several lines of evidence have suggested that the sexual behavior of men can contribute to the risk of cervical cancer in their sexual partners (33-35). Several cancers of the anogenital tract and upper aerodigestive tract and their precursor lesions in men are now understood to be caused by infection with sexually transmitted HPV, and more than one-fourth of HPV-associated cancers in the United States occur in men (36). In Europe, the overall estimated epidemiologic burden of HPV-related cancers and nonmalignant diseases is high in men. Approximately $30 \%$ of all new cancer cases attributable to high-risk HPV types that occur yearly in Europe were estimated to occur in men $(37,38)$. According to an Italian study, the economic burden attributable to noncervical HPV-6, $-11,-16$, and -18-related diseases was higher among men than among women (60.6\% vs. $39.4 \%$ of the total, respectively). The economic costs among men, in fact, represented more than one-third (38.8\%) of the total direct costs of HPV-6, -11, -16, and -18-related diseases, including cervical conditions (cervical cancer, dysplasia, and CIN1/2/3 lesions), i.e., 291 million euros. This observation could inform Italian national and regional health policy evaluations of the economic value of extending the anti-HPV immunization programs to cohorts of boys (39).

\section{REFERENCES}

1. de Martel C, Ferlay J, Franceschi S, Vignat J, Bray F, Forman D, et al. Global burden of cancers attributable to infections in 2008: a review and synthetic analysis. Lancet Oncol 2012;13:607-15.

2. Dunne EF, Nielson CM, Stone KM, Markowitz LE, Giuliano AR. Prevalence of HPV infection among men: a systematic review of the literature. J Infect Dis 2006;194:1044-57

3. Nielson CM, Flores R, Harris RB, Abrahamsen M, Papenfuss MR, Dunne EF, et al. Human papillomavirus prevalence and type distribution in male anogenital sites and semen. Cancer Epidemiol Biomarkers Prev 2007;16: 1107-14.

4. Rocha MG, Faria FL, Goncavales L, Souza Mdo C, Fernandes PA, Fernandes AP. Prevalence of DNA-HPV in male sexual partners of HPV-infected women and concordance of viral types in infected couples. PLOS One 2012;7:e40988

5. Giovannelli L, Bellavia C, Capra G, Migliore MC, Caleca MP, Giglio M, et al. HPV group- and type-specific concordance in HPV infected sexual couples. J Med Virol 2007;79:1882-8

6. Svec A, Mikyskova I, Hes O, Tachezy R. Human papillomavirus infection of epididymis and ductus deferens: an evaluation by nested polymerase chain reaction. Arch Pathol Lab Med 2003;127:1471-4.

7. Martorell M, Gil-Salom M, Pérez-Vallés A, Garcia JA, Rausell N, Senpere A. Presence of human papillomavirus DNA in testicular biopsies from nonobstructive azoospermic men. Arch Pathol Lab Med 2005;129:1132-6.

8. Rintala MA, Grenman SE, Pollanen PP, Suominen JJ, Syrjanen SM. Detection of high-risk HPV DNA in semen and its association with the quality of semen. Int J STD AIDS 2004;15:740-3.

9. Weyn C, Thomas D, Jani J, Guizani M, Donner C, van Rysselberge M, et al. Evidence of human papillomavirus in the placenta. J Infect Dis 2010;203:341-3.

10. Perino A, Giovannelli L, Schillaci R, Ruvolo G, Fiorentino FP, Alimondi P, et al Human papillomavirus infection in couples undergoing in vitro fertilization procedures: impact on reproductive outcomes. Fertil Steril 2011;95:1845-8. 
11. Lai YM, Yang FP, Pao CC. Human papillomavirus deoxyribonucleic acid and ribonucleic acid in seminal plasma and sperm cells. Fertil Steril 1996;65: 1026-30.

12. Lai YM, Lee JF, Huang HY, Soong YK, Yang FP, Pao CC. The effect of human papillomavirus infection on sperm cell motility. Fertil Steril 1997;67:1152-5.

13. Foresta C, Pizzol D, Moretti A, Barzon L, Palù G, Garolla A. Clinical and prognostic significance of human papillomavirus DNA in the sperm or exfoliated cells of infertile patients and subjects with risk factors. Fertil Steril 2010;94: 1723-7.

14. Foresta C, Garolla A, Zuccarello D, Pizzol D, Moretti A, Barzon L, et al. Human papillomavirus found in sperm head of young adult males affects the progressive motility. Fertil Steril 2010;93:802-6.

15. Yang Y, Jia CW, Ma YM, Zhou LY, Wang SY. Correlation between HPV sperm infection and male infertility. Asian J Androl 2013;15:529-32.

16. Garolla A, Pizzol D, Bertoldo A, De Toni L, Berzon L, Foresta C. Association, prevalence and clearance of human papillomavirus and antisperm antibodies in infected semen samples from infertile patients. Fertil Steril 2013; 99:125-31.

17. Schlehofer JR, Boeke C, Reuland M, Eggert-Kruse M. Presence of DNA of adeno-associated virus in subfertile couples, but no association with fertility factors. Hum Reprod 2012;27:770-8.

18. Eggert-Kruse W, Reuland M, Johannsen W, Strowitzki T, Schlehofer JR. Cytomegalovirus (CMV) infection-related to male and/or female infertility factors? Fertil Steril 2009;91:67-82

19. Perez-Andino J, Buck CB, Ribbeck K. Adsorption of human papillomavirus 16 to live human sperm. PLoS One 2009;4:e5847.

20. Kaspersen MD, Larsen PB, Ingerslev HJ, Fedder J, Petersen GB, Bonde J, et al. Identification of multiple HPV types on spermatozoa from human sperm donors. PLoS One 2011;6:e18095.

21. Foresta C, Patassini C, Bertoldo A, Menegazzo M, Francavilla F, Barzon L, et al. Mechanism of human papillomavirus binding to human spermatozoa and fertilizing ability of infected spermatozoa. PLoS One 2011;6:e15036.

22. World Health Organization. WHO laboratory manual for the examination of human semen and sperm-cervical mucus interaction. Cambridge, U.K.: Cambridge University Press; 2010.

23. Giovannelli L, Lama A, Capra G, Giordano V, Aric P, Ammatuna P. Detection of human papillomavirus DNA in cervical samples: analysis of the new PGMY-PCR compared to the hybrid capture $\|$ and MY-PCR assays and two-step nested PCR assay. J Clin Microbiol 2004;42:3861-4.

24. Melchers WJ, Bakkers JM, Wang J, de Wilde PC, Boonstra H, Quint WG, et al. Short fragment polymerase chain reaction reverse hybridization line probe assay to detect and genotype a broad spectrum of human papillomavirus types. Clinical evaluation and follow-up. Am J Pathol 1999;155:1473-8.

25. Schiffman M, Clifford G, Buonaguro FM. Classification of weakly carcinogenic human papillomavirus types: addressing the limits of epidemiology at the borderline. Infect Agents Cancer 2009;4:8.
26. Sarrate $\mathrm{Z}$, Anton $\mathrm{E}$. Fluorescence in situ hybridization (FISH) protocol in human sperm. J Vis Exp 2009;31(pii):1405.

27. Flores-Sànchez I, Gutièrrez-Salinas J, Enriquez-Alvarado E, HernàndezRodriguez S, Ramos-Barragàn C, Salamanca-Ceciliano A, et al. Detection of human papillomavirus types 16 and 18 in semen from patients in an assisted reproduction program. Ginecol Obstet Mex 2010;78:645-51.

28. Giuliano AR, Lazcano-Ponce E, Villa LL, Flores R, Salmeron J, Lee J-H, et al. The Human Papillomavirus Infection in Men study: human papillomavirus prevalence and type distribution among men residing in Brazil, Mexico, and the United States. Cancer Epidemiol Biomarkers Prev 2008;17: 2036-43.

29. Lazcano-Ponce E, Herrero R, Hernández-Ávila M, Salmerón J, Leyva A, Meijer CJ, et al. High prevalence of human papillomavirus infection in Mexican males: comparative study of penileurethral swabs and urine samples. Sex Transm Dis 2001;28:277-80.

30. Lajous M, Mueller N, Cruz-Valdéz A, Aguilar LV, Franceschi S, HernándezAvila $\mathrm{M}$, et al. Determinants of prevalence, acquisition, and persistence of human papillomavirus in healthy Mexican military men. Cancer Epidemiol Biomarkers Prev 2005;14:1710-6.

31. Silva R, León D, Brebi P, lli C, Roa JC, Sánchez R. Diagnóstico de la infección por virus papiloma humano en el hombre. Rev Chilena Infectol 2013;30: 186-92.

32. Giraldo PC, Eleutério JRJ, Cavalcante DIM, Gonçalves AKS, Romão JAA, et al. The role of high-risk HPV-DNA testing in the male sexual partners of women with HPV-induced lesions. Eur J Obstet Gynecol Reprod Biol 2008;137:88-91.

33. Partridge JM, Koutsky LA. Genital human papillomavirus infection in men. Lancet Infect Dis 2006;6:21-31.

34. Giuliano AR, Tortolero-Luna G, Ferrer E, Burchell AN, Sanjose S, et al. Epidemiology of human papillomavirus infection in men, cancers other than cervical and benign conditions. Vaccine 2008;26:K17-28.

35. Muñoz N, Bosch FX. The causal link between HPV and cervical cancer and its implications for prevention of cervical cancer. Bull Pan Am Health Organ 1996;30:362-77.

36. Gillison ML, Chaturvedi AK, Lowy DR. HPV prophylactic vaccines and the potential prevention of noncervical cancers in both men and women. Cancer 2008;113:3036-46.

37. Lenzi A, Mirone V, Gentile V, Bartoletti R, Ficarra V, Foresta C, et al. Rome consensus conference - statement; human papilloma virus diseases in males. BMC Public Health 2013;13:117.

38. Hartwig S, Syrjänen S, Dominiak-Felden G, Brotons M, Castellsagué X. Estimation of epidemiological burden of human papillomavirus-related cancers and nonmalignant diseases in men in Europe: a review. BMC Cancer 2012; $12: 30$.

39. Baio G, Capone A, Marcellusi A, Mennini FS, Favato G. Economic burden of human papillomavirus-related diseases in Italy. PLoS One 2012;7:e49699. 
